\title{
Hellenistic History and Culture
}




\section{HELLENISTIC CULTURE AND SOCIETY}

General Editors: Anthony W. Bulloch, Erich S. Gruen, A. A. Long, and Andrew F. Stewart

I. Alexander to Actium: The Historical Evolution of the Hellenistic Age, by Peter Green

II. Hellenism in the East: The Interaction of Greek and Non-Greek Civilizations from Syria to Central Asia after Alexander, edited by Amélie Kuhrt and Susan Sherwin-White

III. The Question of "Eclecticism": Studies in Later Greek Philosophy, edited by $J . M$. Dillon and A. A. Long

IV. Antigonos the One-Eyed and the Creation of the Hellenistic State, by Richard A. Billows

v. A History of Macedonia, by $R$. Malcolm Errington, translated by Catherine Errington

vi. Attic Letter-Cutters of 229 to 86 B.C., by Stephen V. Tracy

vil. The Vanished Library: A Wonder of the Ancient World, by Luciano Canfora

viII. Hellenistic Philosophy of Mind, by Julia Annas

IX. Hellenistic History and Culture, edited by Peter Green

$x$. The Best of the Argonauts: The Redefinition of the Epic Hero in Book One of Apollonius' Argonautica, by James J. Clauss

XI. Faces of Power: Alexander's Image and Hellenistic Politics, by Andrew Stewart

XII. Images and Ideologies: Self-definition in the Hellenistic World, edited by Anthony W. Bulloch, Erich S. Gruen, A. A. Long, and Andrew F. Stewart

XIII. From Samarkhand to Sardis: A New Approach to the Seleucid Empire, by Susan Sherwin-White and Amélie Kuhrt 


\section{Hellenistic History and Culture}

EDITED AND WITH AN INTRODUCTION BY Peter Green 
The publisher gratefully acknowledges the contribution provided by the General Endowment Fund of the Associates of the University of California Press.

\author{
University of California Press \\ Berkeley and Los Angeles, California \\ University of California Press, Ltd. \\ London, England \\ (C) 1993 by \\ The Regents of the University of California
}

\title{
Library of Congress Cataloging-in-Publication Data
}

Hellenistic history and culture / edited and with an introduction by Peter Green.

p. $\quad \mathrm{cm} .-$ (Hellenistic culture and society: 9)

Includes index.

ISBN 0-520-07564-1 (cloth: alk. paper)

ISBN 0-520-20325-9 (pbk.: alk. paper)

1. Hellenism-Congresses. I. Green, Peter. 1924-

II. Symposium on Hellenistic History and Culture (1988:

University of Texas at Austin) III. Series.

DF77.H5464 1993

938- dc20

Printed in the United States of America

$$
\begin{array}{lllllllll}
1 & 2 & 3 & 4 & 5 & 6 & 7 & 8 & 9
\end{array}
$$

The paper used in this publication meets the minimum requirements of American National Standard for Information Sciences-Permanence of Paper for Printed Library Materials, ANSI Z39.48-1984. () 